Jurnal Tarbawi: Jurnal Ilmu Pendidikan

p-ISSN:1858-1080 | e-ISSN: 2615-6547

Vol. 15, No. 02, Desember 2019, pp. 205-221

\title{
Pengembangan Media Pembelajaran Berbasis Prezi
}

\author{
Eline Yanty Putri Nasution ${ }^{1}$ dan Nur Fauziah Siregar ${ }^{2}$ \\ ${ }^{1}$ Institut Agama Islam Negeri (IAIN) Kerinci \\ ${ }^{2}$ Institut Agama Islam Negeri (IAIN) Padangsidimpuan \\ e-mail: elineyantyputrinasution@iainkerinci.ac.id
}

\begin{abstract}
The aim of this research is to produce a learning media based on Prezi which is valid, practical and effective. This research is a development study using 4-D models consisting of 4 stages, namely: 1) definition, 2) design, 3) development, and 4) dissemination. The learning Media developed in this study is a digital presentation tool based on Prezi geometry material for students of class $4 B$ of the faculty of the LAIN Kerinci Mathematics school year 2017/2018. This Prezi-based learning Media first examined its validity to be tested and implemented in the classroom process. Validation is done by mathematics education experts, basic education and languages. The practicality of learning media is investigated by observing the implementation of the lecture, the filling of a practical poll by students, as well as interviews to students. The effectiveness of learning media is investigated by observing activities and student learning outcomes. All data obtained is analyzed descriptively. Data analysis results show that: 1) the Prezi-based learning medium is valid based on the terms and contents; 2) The Prezi-based learning media can also be said practically based on the implementation of lectures; and 3) Prezi based Learning Media is already effective against the activities and learning outcomes of students. Based on the results of trials and media implementation and data analysis results can be concluded that the learning media based on Prezi is valid, practical and effective.
\end{abstract}

Keywords: Development, Model 4-D, Media, learning, Prezi.

Abstrak. Penelitian ini bertujuan untuk menghasilkan suatu media pembelajaran berbasis Prezi yang valid, praktis dan efektif. Penelitian ini merupakan penelitian pengembangan dengan menggunakan model 4-D yang terdiri atas 4 tahap, yaitu: 1) pendefinisian, 2) perancangan, 3) pengembangan, dan 4) penyebaran. Media pembelajaran yang dikembangkan dalam penelitian ini adalah suatu alat presentasi digital berbasis Prezi pada materi Geometri bagi mahasiswa kelas 4B jurusan Tadris Matematika IAIN Kerinci Tahun Ajaran 2017/2018. Media pembelajaran berbasis Prezi ini terlebih dahulu diperiksa validitasnya untuk kemudian diujicobakan dan diimplementasikan pada proses perkuliahan di dalam kelas. Validasi dilakukan oleh ahli pendidikan matematika, pendidikan dasar dan bahasa. Kepraktisan media pembelajaran diselidiki dengan cara mengamati pelaksanaan perkuliahan, pengisian angket praktikalitas oleh mahasiswa, serta wawancara kepada mahasiswa. Keefektifan media pembelajaran diselidiki dengan cara mengamati aktivitas dan hasil belajar mahasiswa. Seluruh data yang diperoleh dianalisis secara deskriptif. Hasil analisis data menunjukkan bahwa: 1) media pembelajaran berbasis Prezi sudah valid berdasarkan segi konstruk dan isinya; 2) media pembelajaran berbasis Prezi juga sudah dapat dikatakan praktis berdasarkan pelaksanaan perkuliahan; dan 3) media pembelajaran berbasis Prezi sudah efektif terhadap aktivitas dan hasil belajar mahasiswa. Berdasarkan hasil uji coba dan implementasi media serta hasil analisis data dapat disimpulkan bahwa media pembelajaran berbasis Prezi sudah valid, praktis dan efektif.

Kata Kunci: Pengembangan, Model 4-D, Media, Pembelajaran, Prezi. 


\section{PENDAHULUAN}

Tantangan dan persaingan global saat ini membutuhkan Sumber Daya Manusia (SDM) yang berkualitas sehingga Indonesia mampu bertahan dan bahkan maju di tengah perkembangan Ilmu Pengetahuan dan Teknologi (IPTEK) dunia yang pesat, cepat dan berkesinambungan menuju era revolusi industri 4.0. Perguruan Tinggi dalam mewujudkan SDM yang berkualitas hendaknya mampu menghasilkan lulusan yang siap menghadapi tantangan dan persaingan global yang semakin kompleks pada abad ke-21, khususnya persaingan pada Masyarakat Ekonomi ASEAN (MEA). Kualitas SDM lulusan Perguruan Tinggi harus memiliki kemampuan sesuai dengan perkembangan IPTEK, kebutuhan masyarakat, dan kebutuhan pengguna lulusan (Dirjen Pembelajaran dan Kemahasiswaan, 2018). Masih dari sumber yang sama, perguruan tinggi perlu melakukan reorientasi terhadap pengembangan kompetensi mahasiswa sbagai Capaian Pembelajaran Lulusan (CPL) agar dapat hidup lebih baik di era perubahan abad ke-21, memiliki peran aktif di era revolusi industri 4.0, serta mampu membaca tanda-tanda adanya era revolusi industri 5.0. Revolusi industri 5.0 adalah suatu kolaborasi antara manusia dengan sistem cerdas yang berbasis pada internet of thinks (IoT) atau sistem fisik cyber, dengan kemampuan memanfaatkan mesin-mesin cerdas yang lebih efisien dengan lingkungan yang lebih bersinergi (Rada dalam Dirjen Pembelajaran dan Kemahasiswaan, 2018).

Perguruan tinggi dalam mengembangkan kurikulum di era Revolusi Industri 4.0 adalah menghasilkan lulusan yang memiliki kemampuan literasi baru meliputi: 1) literasi data, kemampuan pemahaman untuk membaca, menganalisis, menggunakan data dan informasi di dunia digital; 2) literasi teknologi, kemampuan memahami cara kerja mesin, aplikasi teknologi; 3). literasi manusia, kemampuan pemahaman tentang kemanusiaan, komunikasi dan desain; 4) pemamahaman akan tanda-tanda revolusi industri 4.0; dan 5) pemahaman ilmu untuk diamalkan bagi kemaslahatan bersama secara lokal, nasional, dan global. (Dirjen Pembelajaran dan Kemahasiswaan, 2018).

Kualitas SDM Indonesia berasal dari lulusan perguruan tinggi dengan tingkat kemampuan yang dinyatakan dalam rumusan Capaian Pembelajaran Lulusan (CPL) atau Learning Outcomes, harus mampu mengikuti tantangan dan persaingan global di era revolusi industri 4.0 dan khususnya MEA. Kurikulum Pendidikan Tinggi (KPT) hendaknya dikembangkan sesuai dengan kebutuhan masyarakat dan IPTEK yang dituang dalam CPL. Salah satu contoh capaian pembelajaran pada aspek pengetahuan adalah mahasiswa mampu menguasai konsep teoritis IPTEK, serta menguasai formulasi penyelesaian masalah prosedural di industri. 
Perguruan tinggi yang dihadapkan pada era revolusi industri 4.0 dimana metode pembelajaran yang digunakan diharapkan merupakan kombinasi antara pembelajaran konvensional berbasis kelas dengan pembelajaran daring (online) yang menggunakan teknologi informasi, yang dikenal dengan pembelajaran bauran (blended learning) atau (bybrid learning). Penggunaan pembelajaran bauran sangat sesuai dengan gaya belajar generasi millennia dan generasi-z, dan memberikan kesempatan pada mahasiswa memanfaatkan penggunaan teknologi informasi untuk melakukan penelusuran informasi yang berbasis big data. Penggunaan pembelajaran bauran bagi mahasiswa akan memperkuat literasi digital dan literasi teknologi yang sangat bersesuaian dengan tuntutan kemampuan SDM di era revolusi industri 4.0.

Mahasiswa sebagai calon lulusan di masa depan harus memiliki kemampuan dalam mengaplikasikan bidang keahlian dan memanfaatkan IPTEK pada bidangnya dalam penyelesaian masalah serta mampu beradaptasi dalam berbagai situasi. Penyetaraan mutu lulusan dapat diwujudkan melalui pembelajaran dengan karakteristik interaktif, holistik, integratif, saintifik, kontekstual, tematik, efektif, kolaboratif, dan berpusat pada mahasiswa (Direktorat PTKI, 2018). Tahap pelaksanaan pembelajaran sangat dipengaruhi oleh dosen mahasiswa dan sumber belajar. Ketiga komponen tersebut saling bergantung satu sama lain untuk mewujudkan suatu model baru pendidikan dan meninggalkan pendidikan kuno dalam menjawab tantangan di era revolusi industri 4.0 dan MEA.

Inovasi media pembelajaran merupakan salah satu cara untuk menarik perhatian dan meningkatkan motivasi mahasiswa dalam proses perkuliahan guna mencapai capaian pembelajaran, khususnya pada mahasiswa jurusan Tadris Matematika. Umumnya mata kuliah pada Jurusan Tadris Matematika bersifat hafalan dan berisi materi yang abstrak sehingga membutuhkan pemahaman yang lebih mendalam. Materi yang bersifat hafalan dan abstrak pada umumnya membuat mahasiswa merasa bosan dan kurang antusias dalam mengikuti proses perkuliahan. Sementara itu, materi-materi yang membutuhkan pemahaman mendalam tersebut menuntut mahasiswa untuk lebih berkonsentrasi dalam mengikuti proses perkuliahan sehingga konsep yang dijelaskan dapat dipahami.

Dibutuhkan suatu media pembelajaran untuk menigkatkan pemahaman mahasiswa melalui peningkatan kemampuan ingatan dan partisipasi mahasiswa dalam pembelajaran. Salah satu media pembelajaran yang ditawarkan adalah suatu alat presentasi dramatis dimana mahasiswa menyaksikan demonstrasi visual yang diyakini mampu meningkatkan kemampuan ingatan mahasiswa hingga mencapai lebih dari 50\%. Media pembelajaran yang dimaksud adalah Prezi, yaitu suatu alat presentasi digital yang mampu menyajikan tulisan, gambar, video baik online maupun offline, yang dilengkapi dengan audio dan animasi kekinian yang mampu memberikan 
pengalaman dramatis bagi mahasiswa sehingga materi pembelajaran yang disajikan melalui Prezi berkesan dan membekas di dalam pikiran dan ingatan mahasiswa lebih daripada alat presentasi digital lainnya seperti Power Point dan Macromedia Flash.

Prezi dikembangkan pada tahun 2007 sebagai alat visualisasi arsitektur dan dipublikasi pada tahun 2009 oleh seorang arsitek yang berasal dari Hungaria yaitu Adam Somlai Fischer dan seorang ahli komputer, Peter Halacsy (Rais, 2019). Program ini berfungsi untuk membuat animasi objek, presentasi, animasi iklan, permainan, pendukung aplikasi lain, serta pembuatan film animasi (Wahyudi, 2014). Zooming User Interface (ZUI) terdapat pada Prezi sehingga pengguna mampu memperbesar dan memperkecil tampilan sehingga presentasi terlihat dinamis sebab kanvas dapat diperkecil, diperbesar, bahkan diputar sejauh $360^{\circ}$ (Yusuf, 2014).

Prezi dapat digunakan tidak hanya sebagai media presentasi tetapi juga sebagai alat eksplorasi berbagai ide di kanvas virtual. (zoomable canvas). Adanya kanvas virtual memungkinkan pengguna untuk tidak perlu berpindah slide, pengguna cukup bekerja hanya dengan satu kanvas besar yang dapat disisipkan gambar, video, teks dan lain-lain sebab pengguna dapat membuat slide pada setiap kalimat dengan animasi gerak yang dinamis dan variatif (Prayoga, 2013). Pengguna juga dapat bereksplorasi pada bagian kanvas virtual tersebut hingga bagian yang sangat kecil, sehingga konsep utama yang ingin disampaikan terlihat jelas. Selain itu Prezi dapat disisipkan file Flash, Power Point, Pdf bahkan video dari aplikasi online seperti You Tube, yaitu dengan cara menyalin alamat video tersebut ke bagian kanvas yang akan disisipkan sedemikian sehingga video yang berasal dari You Tube tersebut dapat diputar saat presentasi sedang dijalankan. Hal tersebut mampu menunjang kemudahan untuk menyusun slide presentasi serta file dapat diunduh kedalam bentuk file executable (exe) (Epinur, 2014).

Menurut Rosadi (2013:18) salah satu kelebihan prezi adalah dapat menampung berbagai jenis gaya belajar, karena Prezi didesain agar dapat menampilkan media visual, audio, maupun animasi seperti animasi hand writing, animasi kartun, dan efek transisi yang lebih nyata serta pengaturan timeline yang sangat mudah. Prezi juga merupakan aplikasi presentasi digital yang cukup unik karena memiliki bentuk presentasi yang sangat berbeda dengan presentasi pada umumnya (Yusuf, 2014). Prezi dapat digunakan untuk membuat presentasi linier (terstruktur) dengan cara membangun jalur navigasi presentasi, maupun non-linier seperti peta pikiran (mind map) dengan mengelompokkan objek-objek ke dalam bingkai-bingkai kemudian menentukan ukuran dan posisinya dengan cara mengitari dan menyorot objek-objek tersebut (Settle dalam Antika, 2016). Sebagai media presentasi non-linier, Prezi dapat menyajikan tampilan dari berbagai arah sesuai yang dikehendaki (Suharjanto, 2013). Hal ini berbeda dengan Power Point yang merupakan media presentasi linier yang disajikan secara konsisten dari awal hingga akhir slide. 
Selain itu, Prezi merupakan aplikasi yang berbasis Adobe Air, sehinggga video maupun animasi flash bisa dijalankan lebih ringan daripada mengggunakan Power Point. Beberapa keunggulan Prezi tersebut dapat memberikan kebebasan bagi pengguna untuk menuangkan kreativitasnya dalam pembuatan media presentasi.

Prezi pada awalnya merupakan perangkat lunak berbasis internet (software as a service) yang hanya bisa digunakan secara online namun saat ini pengguna sudah bisa menggunakan aplikasi ini secara offline setelah diluncurkan Prezi Desktop. Pengunduhan Prezi masih berbayar, oleh sebab itu pengguna dapat mengunduh Prezi Trial selama 30 hari. Setelah 30 hari, pengguna dapat menghapus aplikasi Prezi kemudian mengunduh Prezi Trial kembali secara berulang-ulang. Prezi juga membutuhkan kapasitas memori yang besar, yaitu minimal sebesr 1 GB. Desain presentasi digital dengan menggunakan Prezi membutuhkan kreativitas yang tinggi dalam penyusunannya sedemikian sehingga menghasilkan mediapresentasi yang lebih unik, menarik, dan inovatif. Beberapa kekurangan Prezi tersebut dapat diantisipasi demi menghasilkan media pembelajaran dengan menggunakan Prezi yang sangat menarik bagi mahasiswa (Epinur, 2014) sehingga dengan adanya media pembelajaran berbasis Prezi, mahasiswa tidak lagi mengandalkan dosen sebagai narasumber tunggal.

Matematika merupakan salah satu pelajaran yang membutuhkan pola berpikir logis, kritis, dan sistematis. Salah satu substansi matematika yang dianggap sulit adalah Geometri sebab Geometri berkaitan dengan bentuk, ukuran, komposisi dan proporsi suatu benda dengan sifatsifat yang terkait satu sama lainnya (Nasution, 2017). Geometri merupakan cabang matematika yang telah lama dikenal oleh manusia dan selalu ada di setiap tempat dan hampir di setiap objek visual (Dahlan, 2011). Sementera itu, pembelajaran geometri bertujuan untuk mengembangkan kemampuan berpikir logis, kemampuan spasial, menanamkan pengetahuan penunjang bagi materi yang lain, serta dapat membaca dan menginterpretasikan argumen-argumen matematis (Budiarto, 2000). Materi Geometri berkaitan dengan bentuk, ukuran dan posisi suatu objek baik 2 dimensi maupun 3 dimensi yang tentunya membutuhkan daya pikir dan daya visualisasi tingkat tinggi sehingga seseorang sering mengalami kesulitan dalam pembelajaran Geometri.

Latar belakang di atas menjadi acuan penulis untuk mengadakan penelitian tentang pengembangan media pembelajaran berbasis Prezi pada materi Geometri bagi mahasiswa Tadris Matematika IAIN Kerinci. Penelitian ini diharapkan dapat berkontribusi dalam menghasilkan lulusan Tadris Matematika IAIN Kerinci yang mampu bersaing di abad ke-21 ini pada era industri 4.0 dan khususnya pada Masyarakat Ekonomi Asean (MEA). 


\section{METODE}

Penelitian ini merupakan penelitian pengembangan model 4-D terdiri dari 4 tahap, yaitu: 1) pendefinisian (define); 2) perancangan (design); 3) pengembangan (develop); dan 4) penyebaran (dessiminate) (Thiagarajan dkk dalam Trianto, 2010). Pada penelitian ini dikembangkan suatu media pembelajaran berbasis Prezi pada materi Geometri terhadap mahasiswa jurusan Tadris Matematika.

Tahap pendefenisian (define) terdiri atas 5 langkah kegiatan yaitu analisis ujung depan, analisis mahasiswa, analisis tugas, dan analisis konsep serta analisis tujuan pembelajaran. Analisis ujung depan bertujuan untuk mengetahui dan menetapkan masalah dasar yang dihadapi dosen dan mahasiswa dalam pembelajaran Geometri. Berdasarkan hasil analisis ini diperoleh gambaran fakta permasalahan, harapan dan alternatif penyelesaian masalah. Analisis ujung depan dilakukan dengan cara mewawancarai beberapa orang dosen dan mahasiswa tadris matematika yang pernah mengajar dan belajar materi Geometri dengan tujuan untuk mengetahui masalah apa saja yang dihadapi di lapangan sehubungan dengan pembelajaran Geometri tersebut. Analisis ini juga dilakukan berdasarkan pengalaman penulis sebagai dosen Tadris Matematika yang mengajar materi Geometri.

Analisis mahasiswa merupakan telaah karakteristik mahasiswa yang bersesuaian dengan desain pengembangan media pembelajaran pada materi Geometri. Identifikasi ini dilakukan oleh dosen sebagai peneliti dalam mempelajari karakteristik mahasiswa untuk mempermudah penyusunan tata bahasa dalam media pembelajaran dan tingkat kesukaran soal. Selain untuk mengetahui karakteristik mahasiswa, kemampuan akademik, perkembangan kognitif, motivasi belajar serta keterampilan-keterampilan khusus yang dimiliki mahasiswa berkaitan dengan materi Geometri juga dianalisis pada tahap ini. Sama seperti langkah sebelumnya, analisis ini dilakukan dengan cara mewawancarai beberapa orang dosen tadris matematika yang pernah mengajar di kelas praktikalitas. Analisis ini juga dilakukan berdasarkan pengalaman penulis sebagai dosen Tadris Matematika yang pernah mengajar di kelas praktikalitas tersebut. Selain itu, dilakukan juga wawancara terhadap beberapa orang mahasiswa di kelas praktikalitas sebagai cross-check hasil wawancara terhadap dosen Matematika.

Analisis tugas merupakan kumpulan prosedural untuk menentukan isi dalam media pembelajaran berbasis Prezi. Pada analisis tugas ini dilakukan analisis dan reviu materi Geometri yang akan dibahas pada mahasiswa jurusan tadris matematika yang bertujuan untuk melihat kedalaman isi materi, cara penyajian, soal latihan dan tugas dengan tujuan apakah sudah sesuai dengan silabus yang berlaku yang berdasarkan Kerangka Kualifikasi Nasional Indonesia (KKNI) dan Kurikulum Pendidikan Tinggi (KPT) 4.0. 
Analisis konsep dilakukan untuk mengidentifikasi konsep-konsep utama yang akan dijabarkan dalam media pembelajaran yang dikembangkan pada materi Geometri. Materi Geometri merupakan materi yang memiliki substansi yang kompleks, rumit dan mendalam serta membutuhkan daya khayal dalam pemahamannya sehingga dengan adanya analisis ini peneliti akan lebih mudah menyajikan keseluruhan isi materi Geometri secara jelas, sistematis, dan mudah dipahami.

Selanjutnya langkah terakhir pada tahap pendesenifian (define) ini adalah melakukan analisis tujuan pembelajaran, yaitu analisis capaian pembelajaran (learning outcomes) yang dilakukan dengan cara menganalisis Silabus mata kuliah Geometri pada jurusan Tadris Matematika yang bertujuan untuk mengetahui apakah materi yang diajarkan telah sesuai dengan capaian pembelajaran lulusan (CPL) yang diharapkan. Selanjutnya dilakukan analisis terhadap Capaian Pembelajaran Mata Kuliah (CPMK) yang kemudian diuraikan menjadi beberapa sub CPMK. Sub CPMK kemudian diuraikan menjadi beberapa kegiatan pembelajaran. Inti kegiatan langkah terakhir pada tahap pertama metode penelitian ini adalah adanya analisis terhadap Rencana Pembelajaran Semester (RPS) yang bersesuaian dengan Silbus dan Kurikulum yang berlaku.

Hasil kegiatan pada tahap pendefinisian (define) digunakan sebagai acuan pada tahap perancangan (design). Kegiatan yang dilakukan pada tahapa ini adalah merancang media pembelajaran matematika berbasis Prezi, yaitu suatu alat presentasi digital yang memuat seluruh materi yang akan diajarkan.

Tahap Pengembangan (develop) terdiri atas tiga langkah yaitu uji validitas, revisi dan uji pengembangan (praktikalitas) media pembelajaran berbasis Prezi. Pada tahap uji validitas, dilakukan validasi terhadap media pembelajaran berbasis Prezi yang meliputi validitas isi dan validitas konstruk oleh 5 orang ahli dalam Pendidikan Matematika, Pendidikan Dasar dan Bahasa. Validasi isi bertujuan untuk melihat kesesuaian antara media pembelajaran berbasis Prezi yang telah dirancang dengan Silabus dan RPS. Sedangkan validitas konstruk bertujuan untuk melihat kesesuaian komponen-komponen media pembelajaran berbasis Prezi tersebut dengan indikatorindikator model pembelajaran yang telah ditetapkan, yaitu pembelajaran bauran (blended learning/bybrid learning).

Setelah dilakukan uji validitas, langkah berikutnya adalah mengadakan revisi berdasarkan hasil validasi baik validitas isi maupun validitas konstruk yang kemudian divalidasi lagi baik isi maupun konstruknya dan seterusnya sedemikian sehingga media pembelajaran berbasis Prezi sudah dinyatakan valid oleh para validator.

Setelah dilakukan uji validitas dan revisi, langkah terakhir dari tahap kedua ini adalah uji pengembangan (praktikalitas). Uji praktikalitas media pembelajaran berbasis Prezi dilakukan pada 
Mahasiswa Kelas 4B jurusan Tadris Matematika IAIN Kerinci Tahun Ajaran 2017/2018 yang berjumlah 24 orang. Praktikalitas merupakan tingkat keterpakaian media pembelajaran berbasis Prezi meliputi manfaat, kemudahan penggunaan, dan efisiensi waktu pembelajaran menggunakan media pembelajaran tersebut. Angket praktikalitas diisi oleh mahasiswa untuk mengetahui apakah media pembelajaran berbasis Prezi sudah praktis.

Setelah media pembelajaran dinyatakan praktis, kegiatan selanjutnya dipusatkan untuk mengevaluasi apakah media pembelajaran berbasis Prezi dapat digunakan untuk mencapai tujuan yang efektif dalam meningkatkan kualitas dan prestasi belajar mahasiswa. Aspek efektivitas yang diamati dalam proses perkuliahan dengan menggunakan media pembelajaran berbasis Prezi ini adalah aktivitas dan hasil belajar mahasiswa yang dianalisis dengan menggunakan lembar observasi dan pedoman wawancara (Yulia, 2016).

Tahap terakhir pada penelitian ini adalah tahap penyebaran (dessiminate). Pada tahap ini dilakukan promosi terhadap produk hasil pengembangan (develop), yaitu media pembelajaran berbasis Prezi agar dapat diterima oleh pengguna, baik dosen, mahasiswa maupun institusi lain. Setelah media pembelajaran berbasis Prezi dinyatakan valid, praktis dan efektif sesuai dengan hasil yang diperoleh pada langkah sebelumnya, media pembelajaran berbasis Prezi ini disebarkan baik ke kelas lainnya maupun ke perguruan tinggi lainnya. Pada penelitian ini, lokasi penyebaran media pembelajaran berbasis Prezi hanya dibatasi pada satu perguruan tinggi yaitu mahasiswa kelas 3A Program Studi Tadris Matematika IAIN Padangsidimpuan Tahun Ajaran 2019/2020 yang berjumlah 32 orang. Setelah media pembelajaran berbasis Prezi disebarkan, maka dilakukan revisi pada bagian yang masih dianggap kurang berdasarkan hasil praktikalitas media pembelajaran berbasis Prezi di lokasi penyebaran tersebut. Hasil revisi ini menjadi hasil akhir rangkaian pengembangan $x^{`}$ elitian ini terdiri atas instrumen tes yaitu tes hasil belajar dan instrumen non-tes, yaitu angket (kuesioner) yang terdiri atas angket praktikalitas dan skala aktivitas mahasiswa, lembar observasi dan pedoman wawancara. Sebelum instrumen digunakan, terlebih dahulu dianalisis validitas dan reabilitasnya serta tingkat kesukaran soal dan daya pembeda khusus untuk instrumen tes. Setelah instrumen dinyatakan valid dan reliabel, kemudian digunakan untuk mengamati aktivitas, sikap serta hasil belahar mahasiswa pada proses perkuliahan dengan menggunakan media pembelajaran berbasis Prezi.

Terdapat dua jenis data pada penelitin ini, yaitu data kualitatif dan kuantitatif. Data kualitatif diperoleh dari hasil wawancara dan observasi terhadap mahasiswa pada saat uji coba baik uji praktikalitas maupun uji diseminasi, yang berupa masukan, komentar, kritik dan saran. Sedangkan data yang bersifat kuantitatif diperoleh melalui tes hasil belajar mahasiswa dan angket (kuesioner). 


\section{TEMUAN}

\section{Validitas Media Pembelajaran Berbasis Prezi}

Validitas media pembelajaran berbasis Prezi dilakukan oleh lima orang ahli dalam pendidikan matematika, pendidikan dasar dan bahasa. Setelah divalidasi maka media pembelajaran berbasis Prezi direvisi sesuai dengan kritik dan saran validator dan kemudian divalidasi kembali. Kegiatan validasi dan revisi ini berlangsung selama dua kali sedemikian hingga dihasilkan media pembelajaran berbasis Prezi yang sudah valid baik dari segi isi maupun dari segi konstruk. Berikut ini jabaran rerata hasil akhir validitas isi dan konstruk oleh validator:

\section{Tabel 1. Ringkasan Hasil Uji Validitas}

\begin{tabular}{ccccc}
\hline No. & Jenis Validitas & Rata-Rata & Interpretasi & Kesimpulan \\
\hline 1. & Validitas Isi & 3,8 & Sangat Valid & Valid \\
\hline 2. & Validitas Konstruk & 3,7 & Sangat Valid & Valid \\
\hline
\end{tabular}

Media pembelajaran berbasis Prezi sudah valid berdasarkan hasil penilaian dari validator mencakup aspek materi dan aspek penyajian. Berdasarkan aspek materi, alat presentasi digital Prezi disajikan telah sesuai dengan capaian pembelajaran yang diharapkan. Penyajian media pembelajaran telah memberikan kesempatan kepada mahasiswa dalam memahami secara mendalam konsep dan prinsip-prinsip Geometri yang sedang dipelajari. Media pembelajaran berbasis Prezi disajikan dengan urutan yang sistematis dan jelas sehingga menambah daya ingat mahasiswa terhadap materi yang diajarkan.

Berdasarkan aspek penyajian, penggunaan media pembelajaran berbasis Prezi disajikan dengan cara yang mudah, efektif dan efisien serta tahap-tahap dan langkah-langkah penyajian materi sangat logis. Penyajian masalah telah memunculkan proses pembentukan dan pemahaman konsep dalam penyelesaian masalah. Penyajian media pembelajaran berbasis Prezi telah melibatkan mahasiswa secara aktif dalam memahami konsep secara mandiri. Gambar disajikan secara jelas, dengan warna yang bervariasi dan dilengkapi dengan gambar, audio, animasi serta video yang menarik sehingga mampu meningkatkan kemampuan pamahaman mahasiswa terhadap materi Geometri. Media pembelajaran mampu memberikan pengalaman dramatis bagi mahasiswa sehingga membekas dalam ingatan dan memicu mahasiswa untuk menggunakan alat presentasi digital Prezi pada materi lain dan mata kuliah lain.

Berdasarkan aspek bahasa dan keterbacaan, kalimat yang digunakan telah sesuai dengan Bahasa Indonesia yang baik dan benar. Kalimat yang digunakan melibatkan kemampuan berpikir logis mahasiswa dan mudah dipahami. Struktur kalimat telah sesuai dengan tingkat pemahaman mahasiswa, bentuk dan ukuran huruf pada media telah sesuai dengan kapasitas keterbacaan 
mahasiswa. Kalimat yang digunakan dalam penyajian media tidak memberikan makna ganda (ambigu).

\section{Praktikalitas Media Pembelajaran Berbasis Prezi}

Setelah media pembelajaran berbasis Prezi sudah valid maka media pembelajaran berbasis Prezi tersebut diujicobakan pada mahasiswa kelas 4B jurusan Tadris Matematika IAIN Kerinci Tahun Ajaran 2017/2018 yang berjumlah 24 orang. Uji coba media pembelajaran berbasis Prezi bertujuan untuk melihat kepraktisannya. Praktikalitas berarti mudah dan senang dalam menggunakan media tersebut. Kriteria yang dipakai untuk menilai praktikalitas adalah kejelasan materi, kemudahan penggunaan dan kecukupan waktu. Kejelasan mengacu kepada jelasnya penggunaan media oleh dosen dan mahasiswa, sedangkan kemudahan mengacu kepada kemudahan media tersebut saat digunakan oleh dosen dan dipahami oleh mahasiswa. Selanjutnya penggunaan media pembelajaran berbasis Prezi tersebut dapat menjaga efisiensi waktu.

Untuk melihat kepraktisannya, maka dikumpulkan data melalui angket praktikalitas yang diisi oleh mahasiswa, hasil wawancara dengan mahasiswa serta hasil observasi terhadap aktivitas mahasiswa selama proses pembelajaran sedang berlangsung. Berdasarkan analisis data dapat diambil kesimpulan bahwa media pembelajaran berbasis Prezi sudah praktis.

Pelaksanaan pembelajaran dengan menggunakan media pembelajaran berbasis Prezi berjalan dengan baik dan menampilkan kejelasan materi pembelajaran. Penggunaan media pembelajaran berbasis Prezi tidak mendapatkan kendala yang berarti, dengan kata lain situasi berjalan dengan normal sesuai dengan yang direncanakan. Meskipun masih ada beberapa orang mahasiswa yang masih merasa belum jelas terhadap materi yang diajarkan, namun hal tersebut dapat diatasi dengan memberikan penjelasan yang lebih mendalam kepada mahasiswa.

Waktu yang digunakan selama proses praktikalitas media pembelajaran berbasis Prezi sudah sesuai dengan waktu yang disediakan. Waktu pemakaian media pembelajaran berbasis Prezi sudah cukup, namun masih ada beberapa mahasiswa yang masih merasa kekurangan waktu dalam proses pembeajaran. Kekurangan waktu belajar menurut sebagian kecil mahasiswa, dikarenakan sebagian mahasiswa masih ada yang merasakan kesulitan dalam menarik kesimpulan pada akhir pembelajaran. Mereka membutuhkan waktu yang lebih untuk mengulang kembali media pembelajaran sedemikian sehingga memiliki pemahaman yang mendalam terhadap materi. Namun, hal ini tidak mengurangi manfaat dari media itu sendiri sebab kemudahan penggunaan media memungkinkan mahasiswa untuk mengulang sendiri penggunaan media di luar jam pelajaran. Adanya media pembelajaran berbasis Prezi dalam bentuk file executable (exe) juga memungkinkan mahasiswa untuk mengulang materi pembelajaran di rumah. 
Media pembelajaran berbasis Prezi memberikan kemudahan bagi mahasiswa dalam memahami materi Geometri. Penggunaan media dapat memudahkan mahasiswa dalam meningat pelajaran secara rinci dan mendalam. Hal ini disebabkan media pembelajaran berbasis Prezi memberikan pengalaman dramatis bagi mahasiswa sehingga membekas di dalam pikiran mahasiswa.

\section{Efektivitas Media Pembelajaran Berbasis Prezi}

Efektivitas berkaitan dengan dampak media pembelajaran terhadap aktivitas dan hasil belajar mahasiswa. Efektivitas media pembelajaran berbasis Prezi dilihat dari segi aktivitas dan hasil belajar mahasiswa baik pada mahasiswa kelas 4B jurusan Tadris Matematika IAIN Kerinci dan juga di perguruan tinggi diseminasi, yaitu pada mahasiswa kelas 3A Program Studi Tadris Matematika IAIN Padangsidimpuan. Hasil analisis skala aktivitas belajar menunjukkan bahwa media pembelajaran berbasis Prezi dapat memunculkan aktivitas positif dan mengurangi aktivitas negatif mahasiswa. Aktivitas yang paling sering muncul dan sangat berhasil dilaksanakan di kelas adalah visual activities (memperhatikan dosen dan media presentasi) dan listening activities (mendengarkan). Memperhatikan sekaligus mendengarkan pada media presentasi digital berbasis Prezi akan membantu mahasiswa dalam memahami materi dan menambah daya ingat. Hal ini sangat mendukung mahasiswa dengan gaya belajar audio visual.

Aktivitas lainnya yang banyak muncul dan berhasil dilaksanakan adalah oral activities (bertanya pada dosen dan teman) dan mental activities (menanggapi, menganalisis, melihat hubungan dan menyimpulkan pembelajaran). Aktivitas mental activities yang negatif digolongkan ke dalam aktivitas yang tidak berhasil muncul di dalam kelas, karena persentase aktivitas tersebut rendah. Hal ini disebabkan mahasiswa sangat antusias dalam memperhatikan media pembelajaran berbasis Prezi sehingga kegiatan menggangu teman, ribut ataupun kegiatan negatif lainnya hamper tidak pernah muncul. Secara umum, pembelajaran dengan menggunakan media pembelajaran berbasis Prezi dapat meminimalkan munculnya aktivitas negatif. Adapun rangkuman data aktivitas mahasiswa baik di lokasi praktikalitas maupun di lokasi penyebaran dipaparkan pada tabel berikut: 
Tabel 2. Ringkasan Hasil Skala Aktivitas Mahasiswa

\begin{tabular}{cccccc}
\hline No. & $\begin{array}{c}\text { Tahap } \\
\text { Aktivitas }\end{array}$ & $\begin{array}{c}\text { Prakti } \\
\text { kalitas }\end{array}$ & $\begin{array}{c}\text { Penye } \\
\text { baran }\end{array}$ & Rata-Rata & Interpretasi \\
\hline 1. & Visual & $96 \%$ & $98 \%$ & $97 \%$ & Sangat Baik \\
\hline 2. & Oral & $82 \%$ & $80 \%$ & $81 \%$ & Sangat Baik \\
\hline 3. & Listening & $91 \%$ & $90 \%$ & $90,5 \%$ & Sangat Baik \\
\hline 4. & Writing & $75 \%$ & $80 \%$ & $77,5 \%$ & Baik \\
\hline 5. & Motorik & $61 \%$ & $63 \%$ & $62 \%$ & Baik \\
\hline 6. & Mental & $80 \%$ & $83 \%$ & $81,5 \%$ & Sangat Baik \\
\hline 7. & Emotional & $76 \%$ & $77 \%$ & $76,5 \%$ & Baik \\
\hline & Rata-Rata & $80,1 \%$ & $81,6 \%$ & $\mathbf{8 0 , 9 \%}$ & Sangat Baik \\
\hline
\end{tabular}

Hasil belajar merupakan hasil proses belajar, pelaku aktif dalam belajar adalah mahasiswa, hasil belajar mahasiswa diperoleh melalui tes hasil belajar. Berdasarkan analisis data hasil belajar pada mahasiswa kelas 4B jurusan Tadris Matematika IAIN Kerinci dan juga di perguruan tinggi diseminasi, yaitu pada mahasiswa kelas 3A Program Studi Tadris Matematika IAIN Padangsidimpuan, terdapat lebih dari $80 \%$ mahasiswa memperoleh nilai A, yaitu dengan nilai rata-rata hasil belajar 80,5 .

Media pembelajaran yang digunakan dapat meningkatkan minat belajar mahasiswa. Berdasarkan hasil deskripsi dan analisis data, tingkat aktivitas mahasiswa selama proses pembelajaran adalah sangat tinggi. Deskripsi hasil belajar mahasiswa semakin meningkat dengan nilai rata-rata hasil belajar 79 di IAIN Kerinci dan 82 di IAIN Padangsidimpuan dengan tingkat ketuntasan mencapai 100\% baik di IAIN Kerinci maupun di IAIN Padangsidimpuan. Dapat disimpulkan bahwa media pembelajaran berbasis Prezi sudah efektif. Adapun rangkuman hasil belajar mahasiswa dipaparkan pada tabel berikut:

Tabel 3. Ringkasan Tes Hasil Belajar Mahasiswa

\begin{tabular}{cccc}
\hline No. & Tahap & Tingkat Ketuntasan & Rata-Rata \\
\hline 1. & Praktikalitas & $100 \%$ & 79 \\
\hline 2. & Penyebaran & $100 \%$ & 82 \\
\hline & RATA-RATA & $100 \%$ & 80,5 \\
\hline
\end{tabular}

Hasil analisis data menunjukkan bahwa media pembelajaran berbasis Prezi yang dihasilkan sudah valid dari segi isi dan konstruk. Media pembelajaran berbasis Prezi juga sudah praktis, karena mudah, jelas, dan dapat digunakan tanpa kendala. Media pembelajaran berbasis Prezi juga sudah efektif berdasarkan aktivitas mahasiswa dan rata-rata hasil belajar mahasiswa baik pada saat praktikalitas maupun pada saat penyebaran. 


\section{DISKUSI}

Tujuan penelitian ini adalah menghasilkan media pembelajaran berbasis Prezi yang valid, praktis dan efektif. Pengembangan media pembelajaran berbasis Prezi dilakukan berdasarkan adanya tantangan dan persaingan global pada abad ke-21 saat ini serta era revolusi industri 4.0 dan secara khusus pada era Masyarakat Ekoonomi Asean (MEA). Upaya dalam menghadapi tantangan dan persaingan global tersebut adalah dengan meningkatkan kualitas Sumber Daya Manusia (SDM) Indonesia dan khususnya peningkatan mutu lulusan perguruan tinggi. Institut Agama Islam Negeri (IAIN) Kerinci sebagai satu-satunya Perguruan Tinggi Negeri di Kabupaten Kerinci turut berupaya dalam meningkatkan mutu lulusan melalui adanya pengembangan kurikulum melalui penerapan Kurikulum Pendidikan Tinggi (KPT) 4.0 serta penyusunan Rencana Pembelajaran Semester (RPS) 4.0 melalui reorientasi CapaianPembelajaran Lulusan (CPL). Dampak dari pengembangan tersebut adalah pembelajaran bauran (bybrid learning) atau blended learning yang diimplementasikan pada proses perkuliahan. Pembelajaran bauran diikuti dengan adanya inovasi media pembelajaran dengan karakteristik: menarik perhatian; memberikan pengalaman dramatis; menyaksikan demontrasi visual; meningkatkan kemampuan ingatan; serta merangkum materi dengan logis dan sistematis. Salah satu inovasi media pembelajaran yang dimaksud adalah media pembelajaran berbasis Prezi.

Berdasarkan hasil analisis data, media pembelajaran berbasis Prezi yang dihasilkan sudah valid, praktis dan efektif. Media pembelajaran berbasis Prezi sudah valid dari segi isi dan konstruk. Uji validitas ini dilakukan oleh 5 orang validator ahli Pendidikan Matematika, Pendidikan Dasar dan Bahasa. Media pembelajaran berbasis Prezi juga sudah praktis, karena mudah, jelas, dan dapat digunakan tanpa kendala. Hal tersebut diperoleh berdasarkan hasil anlisis angket praktikalitas, lembar observasi dan pedoman wawancara pada uji praktikalitas yang dilakukan terhadap 24 orang mahasiswa kelas 4B Jurusan Tadris Matematika IAIN Kerinci T.A 2017/2018. Media pembelajaran berbasis Prezi juga sudah efektif berdasarkan aktivitas mahasiswa dan rata-rata hasil belajar mahasiswa baik pada saat praktikalitas maupun pada saat penyebaran. Hal tersebut diperoleh berdasarkan hasil analisis skala aktivitas dan hasil tes belajar mahasiswa pada tahap praktikalitas terhadap 24 orang mahasiswa kelas 4B Jurusan Tadris Matematika IAIN Kerinci T.A.2017/2018 dan pada tahap diseminasi terhadap 32 orang mahasiswa Program Studi Tadris Matematika IAIN Padangsidimpuan T.A. 2018/2019.

Aktivitas mahasiswa yang paling sering muncul adalah aktivitas visual yaitu sebesar 96\% pada saat praktikalitas dan sebesar 98\% pada saat penyebaran dengan rata-rata aktivitas sebesar 97\% dalam interpretasi sangat baik. Hal tersebut bersesuaian dengan fungsi media pembelajaran berbasis Prezi sebagai suatu alat presentasi digital dimana mahasiswa menyaksikan demonstrasi 
visual tulisan, gambar, video yang dilengkapi dengan audio dan animasi kekinian yang mampu memberikan pengalaman dramatis bagi mahasiswa sehingga materi pembelajaran yang disajikan melalui Prezi berkesan dan membekas di dalam pikiran dan ingatan. Media pembelajaran berbasis Prezi yang dilengkapi dengan audio menjadi alasan aktivitas listening sebagai aktivitas kedua terbanyak yang muncul, yaitu sebesar $91 \%$ pada saat praktikalitas dan sebesar $90 \%$ pada saat diseminasi dengan rata-rata aktivitas sebesar 90,5\% dalam interpretasi sangat baik. Meskipun media pembelajaran berbasis Prezi menyajikan demonstrasi visual dalam bentuk tulisan, gambar, dan video yang dilengkapi dengan animasi dan audio, aktivitas motorik tetap muncul meskipun menjadi aktivitas yang paling sedikit muncul, yaitu sebesar 61\% pada saat praktikalitas dan 63\% pada saat diseminasi. Hal ini disebabkan karena bahan atau materi pembelajaran yang disajikan pada media pembelajaran berbasis Prezi memuat proyek penemuan Geometri Non-Euclid melalui simulasi kertas sehingga aktivitas motorik tetap muncul dengan interpretasi baik dengan rata-rata 62\%. Hal ini sebagai hasil uji validitas isi oleh validator ahli Pendidikan Matematika yang menyarankan agar media pembelajaran berbasis Prezi mampu mendukung seluruh gaya belajar mahasiswa, yaitu visual, auditory dan kinesthetic (motoric).

Secara keseluruhan, rata-rata aktivitas mahasiswa paling banyak muncul pada saat diseminasi yaitu sebesar $81,6 \%$ sementara rata-rata aktivitas mahasiswa pada saat praktikalitas adalah sebesar 80,1\% namun sama-sama berada pada kategori sangat baik. Hal ini menunjukkan terdapat peningkatan aktivitas mahasiswa meskipun tidak seignifikan. Hal yang menarik adalah terdapat penurunan aktivitas oral dari $82 \%$ pada saat praktikalitas dan menurun menjadi $80 \%$ pada saat diseminasi, namun keduanya sama-sama berada pada kategori sangat baik. Penurunan aktivitas oral ini bersesuaian dengan peningkatan aktivitas visual, artinya mahasiswa lebih senang melihat daripada berbicara. Selanjutnya terjadi penurunan aktivitas listening yaitu sebesar 91\% pada saat praktikalitas dan menurun menjadi $90 \%$ pada saat diseminasi, namun keduanya juga samasama berada dalam kategori sangat baik. Penurunan aktivitas listening ini hanya sebesar $1 \%$. Sebaliknya aktivitas emotional hanya meningkat sebesar $1 \%$ yaitu $76 \%$ pada saat praktikalitas dan $77 \%$ pada saat diseminasi dan keduanya berada pada kategori baik. Secara keseluruhan, peningkatan aktivitas paling tinggi berada pada aktivitas writing, yaitu sebesar 5\% dimana aktivitas writing muncul sebesar 75\% dengan kategori baik pada saat praktikalitas dan sebesar $80 \%$ pada saat diseminasi dengan kategori sangat baik.

Hasil belajar mahasiswa diperoleh dari tes hasil belajar. Rata-rata hasil belajar mahasiswa pada saat praktikalitas adalah 79 (B) sedangkan rata-rata hasil belajar mahasiswa pada saat diseminasi adalah 82 (A). Hasil belajar mahasiswa baik pada saat praktikalitas maupun pada saat diseminasi mencapai tingkat ketuntasan 100\% dengan nilai rata-rata 80,5 (A) 
Penelitian serupa terkait pengembangan media pembelajaran berbasis Prezi dilakukan oleh Muhammad Yusuf Rodhi dan Wasis pada tahun 2014. Media pembelajaran berbasis Prezi dikembangakan dengan menggunakan model ADDIE (Analysis, Design, Develop, Implement, Evaluate) pada materi Kalor untuk meningkatkan keterampilan berpikir kritis siswa. Penelitian tersebut menghasilkan media pembelajaran berbasis Prezi yang memenuhi kriteria kelayakan baik dari segi materi maupun dari segi tampilan media dengan kategori sangat layak. Sementara itu, penelitian ini menghasilkan media pembelajaran berbasis Prezi yang valid baik dari segi isi dan konstruk. Selanjutnya, penelitian terdahulu tersebut mampu meningkatkan keterampilan berpikir kritis siswa dengan n-gain sebesar 0,32 dengan kriteria sedang. Sementara penelitian ini menghasilkan aktivitas mahasiswa sebesar 80,9\% dengan interpretasi sangat baik dan hasil belajar mahasiswa dengan rata-rata 80,5. Berdasarkan hal tersebut, apabila penelitian ini dilanjutkan maka media pembelajaran berbasis Prezi akan dapat meningkatkan kemampuan berpikir kritis mahasiswa.

Penelitiann lainnya mengenai media pembelajaran berbasis Prezi dilakukan oleh Muh Rais pada tahun 2019 untuk mengetahui pengaruh penggunaan multimedia presentasi berbasis Prezi dan gaya belajar terhadap kemampuan mengingat konsep mahasiswa. Penelitian tersebut menghasilkan terdapat perbedaan kemampuan mengingat konsep antara mahasiswa yang dibelajarkan dengan multimedia presentasi Prezi desktop dengan mahasiswa yang dibelajarkan dengan multimedia presentasi Power Point. Hal ini bersesuaian dengan latar belakang pemilihan media pembelajaran berbasis Prezi pada penelitian ini yang terbukti lebih baik daripada media pembelajaran Power Point berdasarkan hasil penelitian terdahulu tersebut. Apabila penelitian ini dilanjutkan maka media pembelajaran berbasis Prezi akan dapat meningkatkan kemampuan pemahaman konsep matematis mahasiswa.

Penelitian ini hanya terbatas pada pengembangan media pembelajaran berbasis Prezi untuk materi Geometri dengan menggunakan model 4-D (define, design, develop, dessiminate). Diharapkan penelitian selanjutnya untuk mengembangkan media pembelajaran berbasis Prezi pada materi lainnya dengan menggunakan model pengembangan lainnya. Penelitian ini juga menelaah aktivitas dan hasil belajar mahasiswa, oleh sebab itu penelitian selanjutnya dapat menelaah kemampuan tingkat tinggi (High Order Thinking Skill) dalam menjawab tantangan dan persaingan global. Media pembelajaran berbasis Prezi juga dapat diteliti dengan menggunakan metode, jenis dan desain penelitian lain untuk meningkatkan kemampuan tingkat tinggi lainnya baik pada bidang Matematika maupun pada bidang lainnya. 


\section{REFERENSI}

Antika, Y., \& Suprianto, B. (2016). Pengembangan Media Pembelajaran Berbasis Prezi sebagai Upaya Meningkatkan Hasil Belajar Siswa Kompetensi Dasar Aplikasi Rangkaian Op Amp Mata Pelajaran Rangkaian Elektronika di SMK Negeri 2 Bojonegoro. Jurnal Pendidikan Teknik Elektro, 5(2).

Budiarto, M. T. 2000. Pembelajaran Geometri dan Berpikir Geometri. Dalam prosiding Seminar Nasional Matematika "Peran Matematika Memasuki Milenium III". Jurusan Matematika FMIPA ITS Surabaya. Surabaya, 2 Nopember.

Dahlan, J. A. 2011. Analisis Kurikulum Matematika. Jakarta: Universitas Terbuka.

Direktorat PTKI. 2018. Panduan Pengembangan Kurikulum PTKI Mengacu pada KKNI dan SN-Dikti. Jakarta: Dirjen Pendidikan Islam Kemenag.

Dirjen Pembelajaran dan Kemahasiswaan. 2018. Panduan Penyusunan Kurikulum Pendidikan Tinggi di Era Industri 4.0 Edisi Ketiga Cetakan ke-1. Jakarta: Dirjen Pembelajaran dan Kemahasiswaan Kemenristekdikti.

Epinur, E., Wilda, S., \& Adriyani, A. (2014). Pengembangan Media Pembelajaran Kimia Pada Materi Elektrokimia Untuk Kelas XII SMA N 8 Kota Jambi dengan Menggunakan Software Prezi. Journal of The Indonesian Society of Integrated Chemistry, 6(1).

Nasution, E. Y. P. (2017). Meningkatkan Kemampuan Spasial Siswa melalui Pembelajaran Geometri Berbantuan Cabri 3D. Mathline: Jurnal Matematika dan Pendidikan Matematika, 2(02), 179-194.

Prayoga, A. M., \& Santoso, S. (2013). Penggunaan Media Prezi Dan Metode Pembelajaran Snowball Throwing Untuk Meningkatkan Prestasi Belajar Akuntansi. Jurnal Pendidikan Ekonomi (JUPE) UNS, 1(2), 1-8.

Rais, M. (2019). Pengaruh penggunaan multimedia presentasi berbasis prezi dan gaya belajar terhadap kemampuan mengingat konsep. Jurnal MEKOM (Media Komunikasi Pendidikan Kejuruan), 2(1).

Suharjanto, A. (2013). Penerapan Media Pembelajaran dengan Penggunaan Software Prezi Dalam Upaya Meningkatkan Minat Belajar Mata Diklat Komunikasi. Jurnal Pendidikan Administrasi Perkantoran Universitas Sebelas Maret, 2(1).

Trianto (2010). Mendesain Model Pembelajaran Inovatif. Progresif Konsep, Landasan, dan Implementasi Pada Kurikulum Tingkat Satuan (KTSP). Kencana, Prenada Media Group, Jakarta

Wahyudi, D. (2014). Pengembangan Multimedia Pembelajaran Interaktif Pendidikan Akhlak Dengan Program Prezi (Studi Di Smp Muhammadiyah 2 Mlati Sleman Tahun Ajaran 2013-2014). Jurnal Pendidikan Sekolab Dasar Abmad Dablan, 1(1), 146-161.

Yulia, P. (2016). Pengembangan Perangkat Pembelajaran Berbasis Problem Based Learning (PBL) untuk Kelas V SD. In SEMINAR NASIONAL (Vol. 1, No. 1). 
Yusuf Rodhi, M. O. H. A. M. M. A. D. (2014). Pengembangan Media Pembelajara Berbasis Prezi untuk meningkatkan keterampilan Berpikir Kritis Pada Materi Kalor. Inovasi Pendidikan Fisika, 3(2). 